\title{
JNPH
}

Volume 6 No. 1 (April 2018)

(C) The Author(s) 2018

\section{PERBEDAAN KADAR GLUKOSA DARAH PUASA PASIEN DIABETES MELITUS TIPE 2 PADA PLASMA NaF BERDASARKAN WAKTU PEMERIKSAAN DI RSUD dr. M. YUNUS PROVINSI BENGKULU TAHUN 2017}

\author{
DIFFERENCES OF BLOOD GLUCOSE BLOOD DIFFERENCES Patients DIABETES \\ MELITUS TYPE 2 IN PLASMA NaF BASED ON TIME IN EXAMINATION IN \\ DR. M. YUNUS BENGKULU IN YEAR 2017
}

\author{
SUSIWATI \\ DOSEN POLTEKKES KEMENKES BENGKULU
}

\begin{abstract}
ABSTRAK
Pemeriksaan glukosa darah diperlukan sebagai penegakan diagnosis penyakit Diabetes Melitus. Dalam keadaan puasa tidak ada makanan yang diabsorbsi. Penundaan pemeriksaan menyebabkan glukosa dapat mengalami penguraian dan nilai yang diperoleh kurang dari nilai yang seharusnya. Antikoagulan NaF digunakan untuk pemeriksaan glukosa darah, karna florida sebagai antiglikolisis menghambat kerja enzim phosphoenol pyruvate dan urease sehingga kadar gula darah diharapkan stabil. Penelitian ini bertujuan untuk mengetahui perbedaan kadar glukosa darah puasa pasien DMT2 pada plasma NaF berdasarkan waktu pemeriksaan yaitu segera diperiksa dan ditunda 2 jam.merupakan penelitian pra eksperimental one group pretestpostest design. Responden sebanyak 30 pasien DMT2. Kadar glukosa diukur menggunakan plasma NaF yang segera diperiksa dan ditunda 2 jam. Hasil kadar gula darah segera diperiksa memiliki nilai rata-rata $219.20 \mathrm{mg} / \mathrm{dL}$ dan nilai rata-rata kadar glukosa dengan penundaan $2 \mathrm{jam}$ adalah $210.67 \mathrm{mg} / \mathrm{dL}$. Perbedaan rerata keduanya sebesar $8.53 \mathrm{mg} / \mathrm{dL}$. Hasil uji $t$ dependent menunjukkan $\mathrm{p}<0.05$ artinya ada perbedaan.Kesimpulan dari penelitian ini terdapat perbedaan antara kadar glukosa darah puasa pada pasien DMT2 menggunakan plasma NaF berdasarkan waktu pemeriksaan.Saran pemeriksaan glukosa sebaiknya dilakukan secara langsung tanpa ditunda agar diperoleh hasil pemeriksaan yang akurat.
\end{abstract}

Kata kunci : Gula Darah Puasa, DMT2, Plasma NaF

\begin{abstract}
Blood glucose examination is needed as a diagnosis of Diabetes Mellitus disease. In a state of fasting no food is absorbed. The delay of examination causes glucose to be degraded and the value obtained is less than the value it should be. Anticoagulant $\mathrm{NaF}$ is used for the examination of blood glucose, because florida as antiglycolysis inhibits phosphoenol enzyme pyruvate and urease enzymes so that blood sugar levels are expected to be stable. This study aims to determine the difference of fasting blood glucose level of DMT2 patients in NaF plasma based on the examination time that is immediately checked and delayed 2 hours. It is pre experimental one group pretest-posttest design. Respondents were 30 patients with DMT2. Glucose levels were measured using $\mathrm{NaF}$ plasma which was promptly checked and delayed for 2 hours. The results of blood sugar levels immediately checked had an average value of $219.20 \mathrm{mg} / \mathrm{dL}$ and the average value of glucose with a delay of 2 hours was $210.67 \mathrm{mg} / \mathrm{dL}$. The average
\end{abstract}


difference of both is $8.53 \mathrm{mg} / \mathrm{dL}$. The results of $\mathrm{t}$ test dependent show $\mathrm{p}<0.05$ means there is a difference. Conclusion of this study there is a difference between fasting blood glucose levels in patients with DMT2 using plasma NaF based on inspection time. Glucose screening checks should be done directly without delay in order to obtain accurate examination results.

Keywords: Fasting Blood Sugar, DMT2, NaF Plasma

\section{PENDAHULUAN}

Diabetes Melitus Tipe 2 ini umumnya dimulai pada usia diatas 40 tahun. Usia 45 tahun merupakan awal terjadinya penuaan atau nama lainnya pra lanjut usia (pralansia). Golongan usia pralansia atau middle age menurut WHO adalah seseorang dengan usia 45-59 tahun dan lansia digolongkan dari usia 60-74 tahun (Mubarak et al., 2009) ${ }^{1}$. Kriteria usia antara 45-64 tahun pada usia tersebut paling banyak terserang penyakit DM yang tidak tergantung insulin atau DMT2 (Depkes RI, 2008) ${ }^{2}$.

World Health Organization (WHO) memprediksi akan terjadi peningkatan jumlah penderita DMT2 yang cukup besar pada tahun-tahun yang akan datang. WHO memprediksikan bahwa peningkatan jumlah penderita penyakit DMT2 di Indonesia yang pada tahun 2000 berjumlah 8,4 juta akan meningkat menjadi sekitar 21,3 juta pada tahun 2030 (Perkeni, 2011) $)^{3}$. Pemeriksaan laboratorium klinik merupakan salah satu faktor penunjang yang penting dalam membantu menegakkan diagnosis suatu penyakit, antara lain ialah pemeriksaan kadar glukosa darah. Pemeriksaan kadar glukosa darah oleh para klinisi baik untuk tujuan skrining atau pemantauan penyakit DM. Akurasi hasil pemeriksaan kadar glukosa darah dipengaruhi oleh banyak faktor, antara lain persiapan pasien yaitu puasa atau tidak, pengumpulan sampel (sampling), preparasi sampel, dan metode pemeriksaan yang digunakan untuk pengukuran kadar glukosa darah.

Natrium fluorida (NaF) adalah antikoagulan yang sering digunakan untuk sampling bahan pemeriksaan kadar glukosa darah, $\mathrm{NaF}$ selain dapat mencegah pembekuan darah, juga telah dinyatakan dapat menghambat proses glikolisis sehingga dapat mempertahankan stabilitas kadar glukosa dalam sampel plasma $\mathrm{NaF}$ (American Association for Clinical Chemistry, 2002) ${ }^{4}$. Pemeriksaan kadar glukosa selain menggunakan plasma $\mathrm{NaF}$ juga sering menggunakan sampel serum (Gandasoebrata, $2004)^{5}$. Dalam penelitian Erny Julitania tahun 2011, yang menggunakan sampel glukosa darah sewaktu dan pada responden yang memiliki kadar glukosa darah normal mengatakan bahwa kadar glukosa dalam plasma $\mathrm{NaF}$ stabil dalam bila dibandingkan dengan sampel serum dalam 2 jam pertama pasca sampling.

\section{Diabetes Melitus Tipe 2}

Diabetes melitus tipe 2 adalah hasil dari gangguan sekresi insulin yang progresif yang menjadi latar belakang terjadinya resistensi insulin. Resistensi insulin pada DMT2 disertai dengan penurunan reaksi intrasel ini. Sehingga insulin menjadi tidak efektif untuk menstimulasi pengambilan glukosa oleh jaringan. Upaya untuk mengatasi resistensi insulin dan mencegah terbentuknya glukosa dalam darah, harus terdapat peningkatan jumlah insulin yang disekresikan.

Pada penderita dengan toleransi glukosa terganggu, keadaan ini terjadi akibat sekresi insulin yang berlebihan, dan kadar glukosa akan dipertahankan pada tingkat yang normal atau sedikit meningkat. Namun demikian jika sel-sel beta tidak mampu mengimbangi peningkatan kebutuhan akan insulin, maka kadar glukosa akan meningkat dan terjadi DMT2. Diabetes tipe ini pada mulanya diatasi dengan diet dan latihan, jika kenaikan glukosa darah tetap terjadi, terapi diet dan latihan tersebut dilengkapi dengan obat hipoglikemik oral(Price \& Wilson, 2005) ${ }^{6}$. 


\section{Glukosa Darah Puasa}

Pemeriksaan digunakan untuk mengetahui kemampuan seseorang dalam mengatur kadar glukosa darah supaya dapat terkontrol secara baik. Sebelum dilakukan pemeriksaan pasien dianjurkan agar puasa lebih dahulu puasa selama 8-10 jam. Dalam keadaan puasa tidak ada makanan yang di absorbsi. Maka proses untuk mempertahankan kadar glukosa normal tergantung dari interaksi yang terintegtasi baik antara hati, jaringan perifer dan hormonhormon yang dapat meningkatkan atau menurunkan kadar glukosa darah ${ }^{6}$.

Tabel 1. Kadar glukosa darah puasa sebagai patokan penyaring dan diagnosis DM (mg/dl)

\begin{tabular}{|c|c|c|c|c|}
\hline & & $\begin{array}{c}\text { Bukan } \\
\text { DM }\end{array}$ & $\begin{array}{c}\text { Belum } \\
\text { pasti }\end{array}$ & $\mathrm{DM}$ \\
\hline $\begin{array}{c}\text { Kadar } \\
\text { glukosa }\end{array}$ & $\begin{array}{c}\text { Plasma } \\
\text { vena }\end{array}$ & $<100$ & $100-125$ & $\geq 126$ \\
\hline $\begin{array}{l}\text { darah puasa } \\
(\mathrm{mg} / \mathrm{dl})\end{array}$ & $\begin{array}{l}\text { Darah } \\
\text { kapiler }\end{array}$ & $<90$ & $90-99$ & $\geq 100$ \\
\hline
\end{tabular}

(Sumber : PERKENI, 2011)

Metode ini digunakan untuk pengukuran glukosa. Metode ini dianjurkan oleh WHO dan IFCC. Prinsip pemeriksaan pada metode ini adalah heksokinase akan mengkatalisis reaksi fosforilasi glukosa dengan ATP, membentuk glukosa-6-fosfat, dan ADP. Enzim kedua yaitu glukosa-6posfat dengan nicotinamide adenin dinocloetide phosphate (NADP).

Gambar 1. Reaksi yang terjadi pada heksokinase (Depkes,2005) ${ }^{7}$

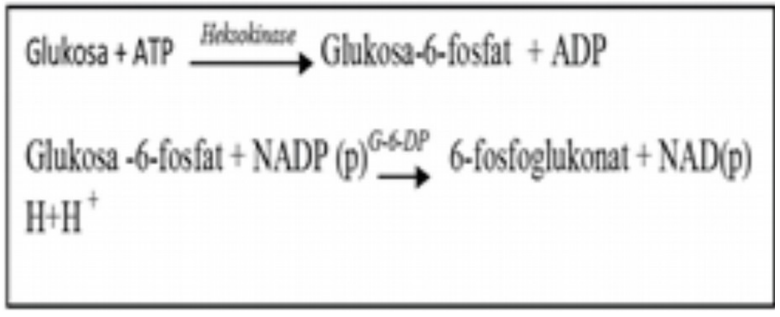

Metode heksokinase jarang digunakan karena menggunakan alat-alat yang otomatis. Kelebihan metode ini yaitu lebih kecil kemungkinan untuk terjadi human error (kesalahan oleh manusia). Waktu inkubasi sedikit lebih cepat dan penggunaan reagen lebih irit bila dibandingkan dengan metode GOD-PAP. Pemeriksaan kadar glukosa sekarang sudah diisyaratkan dengan cara enzimatik, tidak lagi dengan prinsip reduksi untuk menghindari ikut terukurnya zat-zat lain yang akan memberikan hasil tinggi/rendah palsu.

\section{Faktor-faktor yang Memengaruhi Hasil Pemeriksaan Glukosa Darah}

Penundaan pemeriksaan serum dapat menyebabkan penurunan kadar glukosa darah yang disebabkan oleh :

1. Glikolisis

2. Jumlah sel darah yang tinggi juga menyebabkan glikolisis yang berlebihan

3. Kontaminasi bakteri

4. Suhu dan masa penyimpanan

\section{METODOLOGI PENELITIAN}

Penelitian ini menggunakan jenis penelitian pra eksperimental one group pretest-posttest design yaitu penelitian yang tidak ada kelompok pembanding (kontrol) tetapi dilakukan observasi pertama (pretest) yang memungkinkan perubahan yang terjadi setelah adanya eksperimen (Notoatmodjo, $2012)^{8}$. Pada penelitian ini dilakukan pretest yaitu pemeriksaan kadar glukosa plasma $\mathrm{NaF}$ yang langsung diperiksa dan postest yaitu pemeriksaan kadar glukosa plasma $\mathrm{NaF}$ setelah penundaan selama 2 jam.

\section{HASIL}

\section{Karakteristik umum responden}

Tabel 2. Distribusi Karakteristik berdasarkan jenis kelamin 


\begin{tabular}{ccc}
\hline Jenis kelamin & frekuensi & Persen $\%$ \\
\hline perempuan & 15 & 50.0 \\
\hline Laki laki & 15 & 50.0 \\
\hline & 30 & 100 \\
\hline
\end{tabular}

Dari tabel 2 dapat diketahui distribusi frekuensi karakteristik berdasarkan jenis kelamin. Berdasarkan jenis kelamin pada 30 orang responden didapat hasil 15 orang berjenis kelamin laki-laki $(50.0 \%)$ dan 15 orang berjenis kelamin perempuan $(50 \%)$.

Tabel 3. Distribusi Karakteristik berdasarkan Umur

\begin{tabular}{ccc}
\hline Umur & frekuensi & Persen $\%$ \\
\hline $40-49$ & 13 & 43.3 \\
\hline $50-59$ & 13 & 43.3 \\
\hline $60-65$ & 4 & 13.3 \\
\hline & 30 & 100 \\
\hline
\end{tabular}

Berdasarkan umur pada 30 orang responden didapat hasil 13 orang memiliki rentang usia 40-49 tahun (43.3\%), 13 orang memiliki rentang usia 50-59 tahun (43.3\%) dan 4 orang berusia 4 tahun (13.3\%).

Analisa bivariat dilakukan untuk melihat perbedaan kadar glukosa darah puasa plasma $\mathrm{NaF}$ berdasarkan waktu pemeriksaan pada pasien DMT2 rawat jalan di RSUD Dr. M. Yunus Bengkulu tahun 2016 dengan menggunakan uji $t$ dependent yang dapat dilihat pada tabel berikut:

Tabel 4. Perbedaan Kadar Glukosa Darah Puasa Pasien Diabetes Melitus Tipe 2 pada Plasma NaF berdasarkan waktu pemeriksaan di RSUD dr. M. Yunus Provinsi Bengkulu Tahun 2016

\begin{tabular}{|c|c|c|c|c|c|}
\hline Variabel & $\mathrm{n}$ & $\begin{array}{c}\text { Mean } \pm \\
\text { SD }\end{array}$ & $\begin{array}{c}\text { Mean } \\
\text { difference } \\
\pm \mathrm{SD} \\
\end{array}$ & $\begin{array}{c}\text { IK } 95 \\
\%\end{array}$ & $P$ value \\
\hline $\begin{array}{c}\text { Kadar GDP } \\
\text { segera }\end{array}$ & 30 & $\begin{array}{c}219.20 \pm \\
98.81\end{array}$ & $\begin{array}{c}8.533 \pm \\
2.886 \\
\end{array}$ & $\begin{array}{c}9.61- \\
7.45 \\
\end{array}$ & 0.000 \\
\hline $\begin{array}{c}\text { Kadar GDP } \\
\text { tunda } 2 \\
\text { jam }\end{array}$ & 30 & $\begin{array}{c}210.67 \pm \\
97.85\end{array}$ & & & \\
\hline
\end{tabular}

Setelah dilakukan uji $t$ dependent untuk melihat apakah ada perbedaan antara kedua pemeriksaan, Dari tabel 4.2 tersebut dapat dilihat nilai $p$ value sebesar $0.000(\mathrm{p}<0,05)$, yang artinya terdapat perbedaan rata-rata hasil pemeriksaan glukosa darah pada plasma $\mathrm{NaF}$ yang segera di periksa dan ditunda pemeriksaannya selama 2 jam.

\section{PEMBAHASAN}

Hasil penelitian ini menunjukkan bahwa terdapat perbedaan terhadap hasil pemeriksaan glukosa darah puasa menggunakan plasma $\mathrm{NaF}$ yang segera diperiksa dan ditunda selama 2 jam, ini menunjukkan bahwa kadar glukosa dalam sampel darah yang ditunda telah menurun karna adanya proses glikolisis. Hal ini serupa dengan teori yang menjelaskan bila sampel darah telah dikeluarkan dari dalam tubuh, jika tidak segera dilakukan pemeriksaan akan terjadi penurunan kadar dikarenakan glukosa darah dapat mengalami proses penguraian / proses glikolisis. Penundaan pemisahan serum atau plasma mengakibatkan penurunan kadar glukosa darah, karena sebagian glukosa darah akan terpakai untuk metabolisme glukosa dalam sampel, oleh sel sel darah seperti eritrosit, leukosit, trombosit sampai terjadi pemisahan melalui proses sentrifugasi. Sebaiknya plasma segera dipisahkan dari eritrosit sebelum 1 jam dan diperiksa dalam jangka waktu kurang dari 1 jam (Suryaatmadja, 2003) ${ }^{9}$.

Suhu dan masa penyimpanan juga sangat mempengaruhi dan berdampak pada akurasi dan ketepatan hasil pengukuran kadar glukosa darah. Pada suhu kamar kadar glukosa darah dalam sampel akan lebih cepat menurun bila di bandingkan dengan sampel yang disimpan pada almari pendingin (Widyastuti, 2011) ${ }^{10}$. Penurunan kadar glukosa darah pada pasien Diabetes Melitus disebabkan sel-sel darah sudah mengalami kerusakan dan rentan kontaminasi mikroorganisme, sehingga proses glikolisis terjadi cukup cepat dan banyak. Darah individu yang mengalami infeksi sering 
mengandung mikroorganisme penyebab infeksi. Jumlah sel darah yang tinggi juga menyebabkan glikolisis yang berlebihan sehingga terjadi penurunan kadar glukosa. Semua unsur kehidupan membutuhkan energi untuk metabolisme dan sumber energi utama mahluk hidup adalah glukosa (Irawan, 2007) ${ }^{11}$.

Antikoagulan merupakan bahan baku tambahan yang digunakan untuk mencegah sampel darah membeku. NaF (Natrium Flourida) merupakan antikoagulan yang sering digunakan untuk pemeriksaan glukosa darah karena flourida sebagai antiglikolisis dianggap dapat menghambat penurunan kadar glukosa darah dengan cara menghambat kerja enzim phosphoenol pyruvate dan urease sehingga kadar glukosa darah diharapkan dapat stabil ${ }^{10}$. Antikoagulan $\mathrm{NaF}$ konvensional dalam bentuk serbuk dapat digunakan dengan perbandingan $2 \mathrm{mg}$ untuk tiap $1 \mathrm{~mL}$ darah. NaF juga tersedia di dalam tabung vacum berwarna abu abu dimana untuk tabung vacum yang berukuran $2 \mathrm{~mL}$ telah bersisi antikoagulan $\mathrm{NaF}$ sebanyak 4 mg. Kemampuan $\mathrm{NaF}$ dalam menghambat proses glikolisis belum diketahui secara jelas. Pemeriksaan glukosa darah selain menggunakan plasma $\mathrm{NaF}$ juga sering menggunakan sampel serum (Gandasoebrata, 2004) ${ }^{5}$.

\section{KESIMPULAN}

Berdasarkan hasil penelitian dan analisis data tentang "perbedaan kadar glukosa darah puasa pasien Dabetes Melitus tipe 2 pada Plasma NaF berdasarkan waktu pemeriksaan di RSU dr. M. Yunus Provinsi Bengkulu tahun 2016" yang telah dilakukan, maka dapat disimpulkan sebagai berikut :

Terdapat perbedaan kadar glukosa darah pada Plasma NaF, sebaiknya sampel segera diperiksa karna penundaan selama 2 jam menyebabkan terjadinya penurunan kadar glukosa dalam sampel.

\section{SARAN}

1. Bagi institusi terkait yaitu menambah referensi mengenai penanganan terhadap sampel untuk pemeriksaan glukosa darah sebaiknya segera diperiksa tanpa penundaan.

2. Bagi masyarakat yaitu untuk memberikan informasi untuk selalu mengontrol kadar glukosa darah puasa, agar diperoleh hasil yang tepat dan akurat sebagai kontrol dan pemantauan terhadap penyakit Diabetes Melitus.

3. Bagi pendidikan dan pengetahuan yaitu dilakukan penelitian lanjutan untuk mengetahui stabilitas dari antikoagulan $\mathrm{NaF}$ dalam menghambat glikolisis.

\section{DAFTAR PUSTAKA}

American Diabetes Association (ADA). 2010. Standards Of Medical Care In Diabetes2015. The Journal of Clinical And Applied Research And Education, 38(January), 99.

Departemen Kesehatan. Pharmaceutical care untuk Penyakit Diabetes. 2005

Departemen Kesehatan. Pharmaceutical care untuk Penyakit Diabetes. 2005

DepkesRI. 2008. Pedoman-TeknisPenemuan-Dan-TatalaksanaDM 2008.Pdf.

Irawan, A. 2007. Metabolisme Energi Tubuh dan Olahraga. Jakarta

Mubarak,et al. 2009. Ilmu Keperawatan Komunitas Konsep dan Aplikasi. Jakarta : Salemba Medika

Notoatmodjo, S. 2012. Metodologi Penelitian Kesehatan, cetakan kedua. Jakarta : Rieka Cipta

Perkumpulan Endokrinologi Indonesia (PERKENI).2011.KonsensusPengelola an Dan Pencegahan Diabetes Melitus Tipe 2 Di Indonesia 2011

Price and Wilson. 2005. Konsep Klinis Proses-Proses Penyakit Edisi 6. Vol.2. Jakarta: EGC

Suryaatmadja, M. 2003. Pendidikan Berkesinambungan Patologi Klinik. 
Jakarta: Bagian Patologi Klinik Fakultas Kedokteran Universitas Indonesia.

Widyastuti, I. 2011. Perbedaan Kadar Glukosa Darah Puasa Menggunakan Sampel Plasma EDTA dan Serum Yang langsung Di Periksa dan Ditunda selama Dua Jam. Fakultas Ilmu Kedokteran Universitas Muhammadiyah Semarang. 